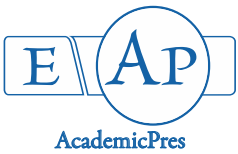

Bamigboye RA et al. (2020)

Notulae Scientia Biologicae 12(1):1-13

DOI: $10.15835 / \mathrm{nsb} 12110644$

Research Article

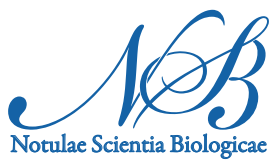

\title{
Systematic significance of stipe anatomy of Pteris L. (Pteridaceae) from Southwestern Nigeria
}

\author{
Rachael A. BAMIGBOYE ${ }^{1 *}$, Fatai A. OLOYEDE², \\ Akinwumi J. AKINLOYE ${ }^{2}$ \\ ${ }^{1}$ Obafemi Awolowo University, Natural History Museum, Ile-Ife, Nigeria; bamigboyeadebola@yahoo.com (*corresponding author) \\ 2Obafemi Awolowo University, Department of Botany, Ile-Ife,_Nigeria; funsoji@oauife.edu.ng; akinloye_jobnson@yahoo.com
}

\begin{abstract}
Stipe anatomy of seven Pteris species collected from various locations in the Southwestern Nigeria was investigated. This was with a view to identify characters of the stipe anatomy that are important in delimiting the species. Transverse sections (TS) of stipe at proximal median and distal regions were cut with the aid of a Reichert Austria sledge microtome at $10 \mu$ thickness. Sections were stained in Safranin O for five minutes, rinsed in three successive changes of water and counterstained in Alcian blue for five minutes. The counterstained sections were rinsed in three changes of water, and then treated in serial grades of alcohol. Observation of prepared slides was made under light microscope. Based on the shape of the vascular bundles, the Pteris species fall into three categories which are inverted Omega, $\mathrm{V}$ or $\mathrm{U}$ shapes. The adaxial grooves varied from proximal to distal regions in all the species except in P. ensiformis where it was uniform throughout the regions.
\end{abstract}

Keywords: anatomy; Pteris L.; taxonomy; stipe; vascular bundles

\section{Introduction}

Pteris L. belongs to the family Pteridaceae with a global distribution especially in Africa, and America. It comprises 250 species of which 61 occur in Africa (Roux, 2009). Unsuccessful attempts have been made to either unite it with other genera in a higher monophyletic unit or divide it into a convenient natural group (Price, 1974). Many of the infrageneric groups in the genus Pteris form intricate complexes and makes critical characters for identification difficult.

Anatomical features of the stipes have proven to be useful for taxonomic purposes (Ummu-Hani et al., 2013). With more available data identification process becomes much easier for distinguishing species. Moreover, vascular anatomy of ferns has been useful in showing successive stages of development, position, interrelationship and structure of different vascular components of the mature fern and even phylogenetic relationship (Remsi et al., 2016). However, the stipe anatomy of some members of Pteridaceae from regions of America have been carried out but none on Nigerian species, hence this study. 


\section{Materials and Methods}

\section{Transverse sections of stipes (petiole)}

The transverse sections of the stipes from each of the seven of Pteris species studied were done at $10 \mu \mathrm{m}$ using Reichert Austrie sledge microtome. Sections were preserved in 50\% ethanol. The sections were stained in Safranin O for five minutes, rinsed in three successive changes of water and then counter stained in Alcian blue for five minutes. The counter stained sections were rinsed again in water and then treated in serial grades of alcohol $(50 \%, 60 \%, 70 \%, 80 \%, 90 \% 100 \%)$ for dehydration and differentiation processes. The sections were mounted on clean slides in $25 \%$ glycerol. Photomicrographs were taken with the aid of Accu-scope trinocular microscope (ACCU-scope 33001 LED Trinocular microscope with $3.2 \mathrm{MP}$ CMOS digital camera) and microscopic observations of the anatomic features of the stipes were done, described and recorded.

\section{Results}

\section{P. togoensis (Figures 1- 6)}

Outline: Apple or heart shaped in proximal and median, spherical in distal region with adaxial concave and abaxial convex.

Cuticle: Thin and gently undulating.

Epidermal appendages: None

Epidermis: Uniseriate and biseriate; shape circular to oval.

Cortex: The cortex consists of three to ten layers of polygonal sclerenchyma cell lies after the epidermis. Parenchyma cells circular oval and polygonal

Vascular bundle: Amphicribral, V-shaped, fused, conjoint and concentric.

P. vittata (Figures 1-6)

Outline: Apple shaped

Cuticle: Prominent, relatively thicker than the other species, striated and gently undulating Epidermal appendages: Short muticellular and multiseriate trichomes present

Epidermis: Uniseriate

Cortex: It consists of oval circular and polygonal shaped parenchyma cells.

Cell inclusions: Crystal druses present in proximal region

Vascular Bundle: Amphicribral, V-shaped, fused, conjoint and concentric.

\section{P. ensiformis (Figures 1 - 6)}

Outline: Pussycat face, adaxial flattened, abaxial convex in all regions.

Cuticle: Prominent and undulating.

Epidermal appendages: None.

Epidermal cell: Some portion of the epidermal cell are not distinguishable from the

sclerenchyma cell that followed the epidermis other portions are either uniseriate or biseriate. The cylindrical shaped sclerenchyma cell extends from cortex to epidermis. A small portion on the adaxial surface has its epidermis distinguished from the sclerenchyma of the cortex. Epidermal cells are circular or oval while the sclerenchyma cell is polygonal.

Cortex: Most portion of the cortex is occupied by parenchyma, their shapes ranges from circular, oval, short rectangular to polygonal.

Cell inclusions: Crystal druses are present in the parenchyma cell of the cortex and in the phloem in the distal region while styloid crystals are present in the proximal region.

Vascular bundle: V shaped, fused, coinjoint, concentric, amphicribral. 
P. mildbraedii (Figures 1- 6)

Outline: Apple shaped, adaxial concave, abaxial surface convex in all the regions.

Cuticle: Thin and undulating.

Epidermal appendages: None

Epidermis: Uniseriate, biseriate, 1-3 layers of elongated, cylindrical shaped cells

Cortex: Few lays of schlerenchyma cell run from epidermis to the cortex. Cortex mostly occupied by circular, oval, short cylindrical, polygonal shaped parenchyma cells.

Cell inclusions: Crystal druses present in all the regions,

Vascular bundle: Omega shape, fused, conjoint concentric and amphicribral.

P. similis (Figures 1- 6)

Outline: Circular in proximal and distal, but slightly depressed in the median region forming more or less apple shape

Cuticle: Thin, gently undulating.

Epidermal appendages: Trichomes are present.

Epidermal cell: Uniseriate, circular, oval in shape,

Cortex: The cortex consists of four to eight layers of sclerenchyma cell, polygonal in shapes. Parenchyma cell are mostly circular, few polygonal and oval.

Cell inclusions: Crystal druses present in proximal and distal regions.

Vascular bundle: Omega shaped, fused, conjoint and concentric amphicribral.

P. togoensis (Figures 1-6)

Outline: Apple or heart shaped in proximal and median, spherical in distal region with adaxial concave and abaxial convex.

Cuticle: Thin and gently undulating.

Epidermal appendages: None

Epidermis: Uniseriate and biseriate; shape circular to oval.

Cortex: The cortex consists of three to ten layers of polygonal sclerenchyma cell lies after the epidermis. Parenchyma cells circular oval and polygonal 

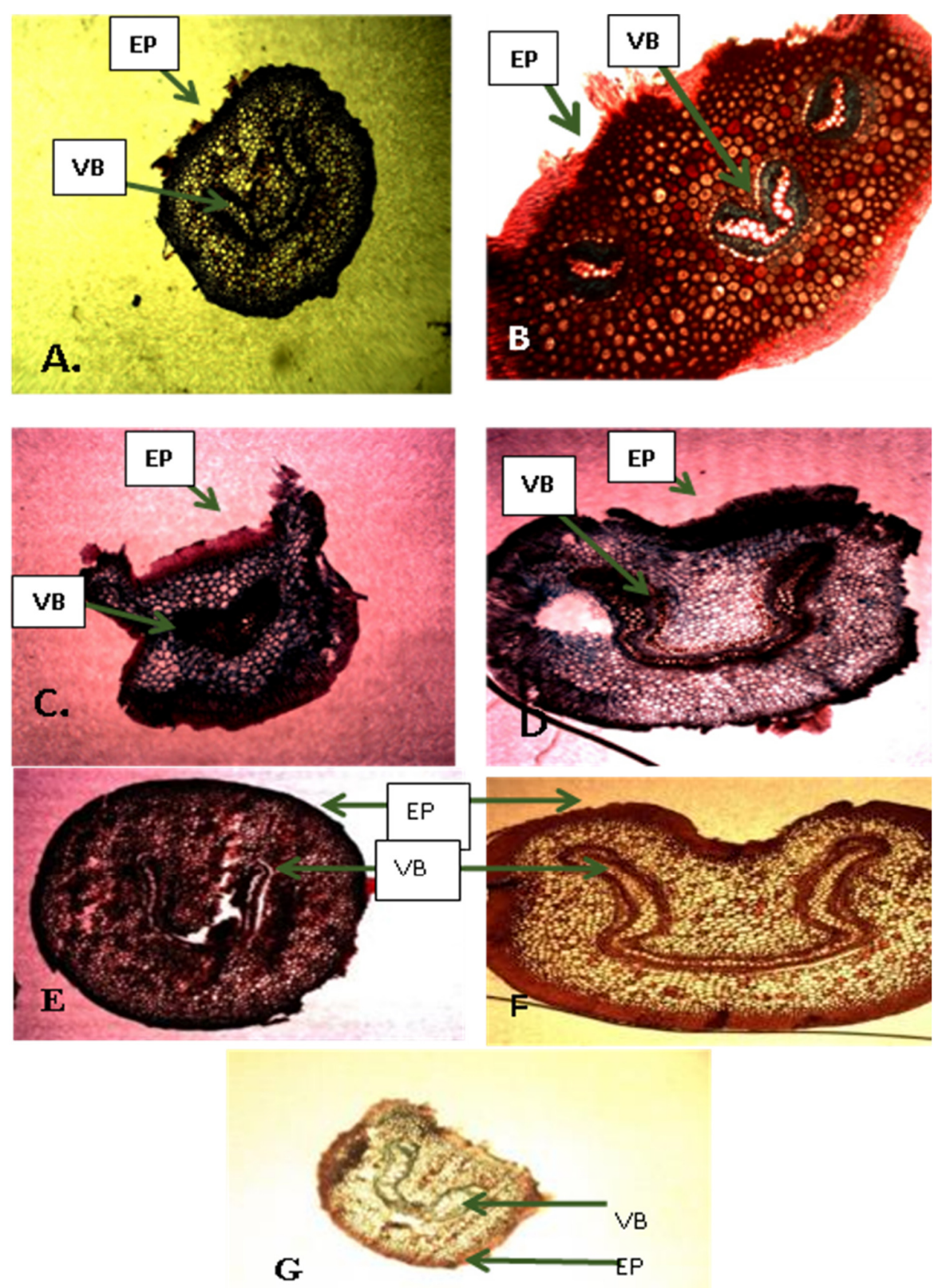

Figure 1. Transverse sections of the proximal regions of stipe showing outlines in seven species of Pteris studied. A: P. acanthoneura, B: P. atrovirens, C: P. ensiformis, D: P. mildbraedii. E: P similis, F:P. togoensis, G: P. vittata. Legend- EP: Epidermis, VB: Vascular bundle Legend: EP- Epidermis; VB- Vascular Bundle. Bar $=1000 \mu \mathrm{m}$ 

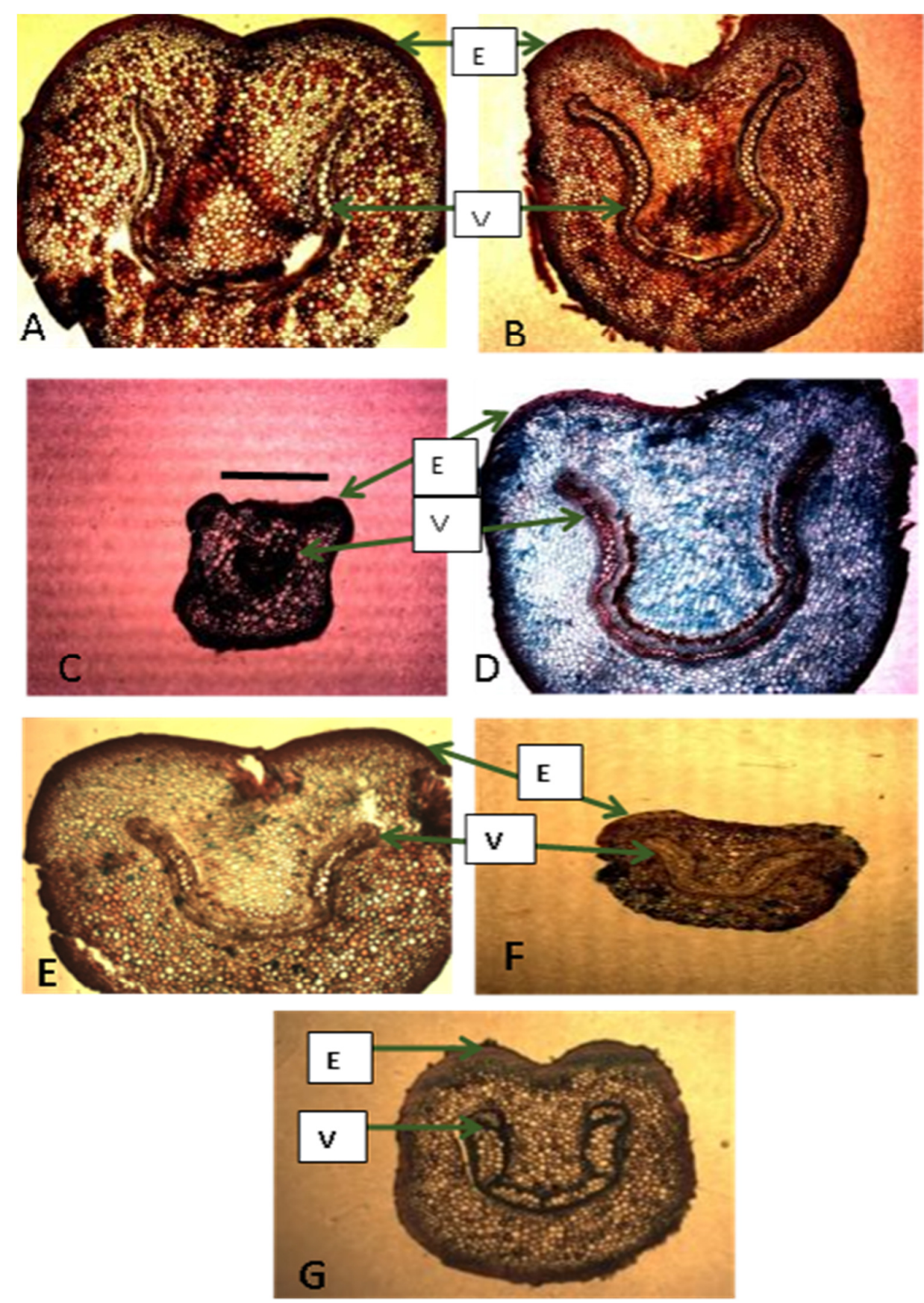

Figure 2. Transverse sections of the median regions of stipes showing outlines in seven species of Pteris studied. A: P. acanthoneu, B: P.atrovirens, C: P. ensiformis and D: P. mildbraedii, E: P similis, F: P.togoensis and G: P. vittata

Legend: EP: Epidermis; VB: Vascular bundle, Bar $=1000 \mu \mathrm{m}$ 

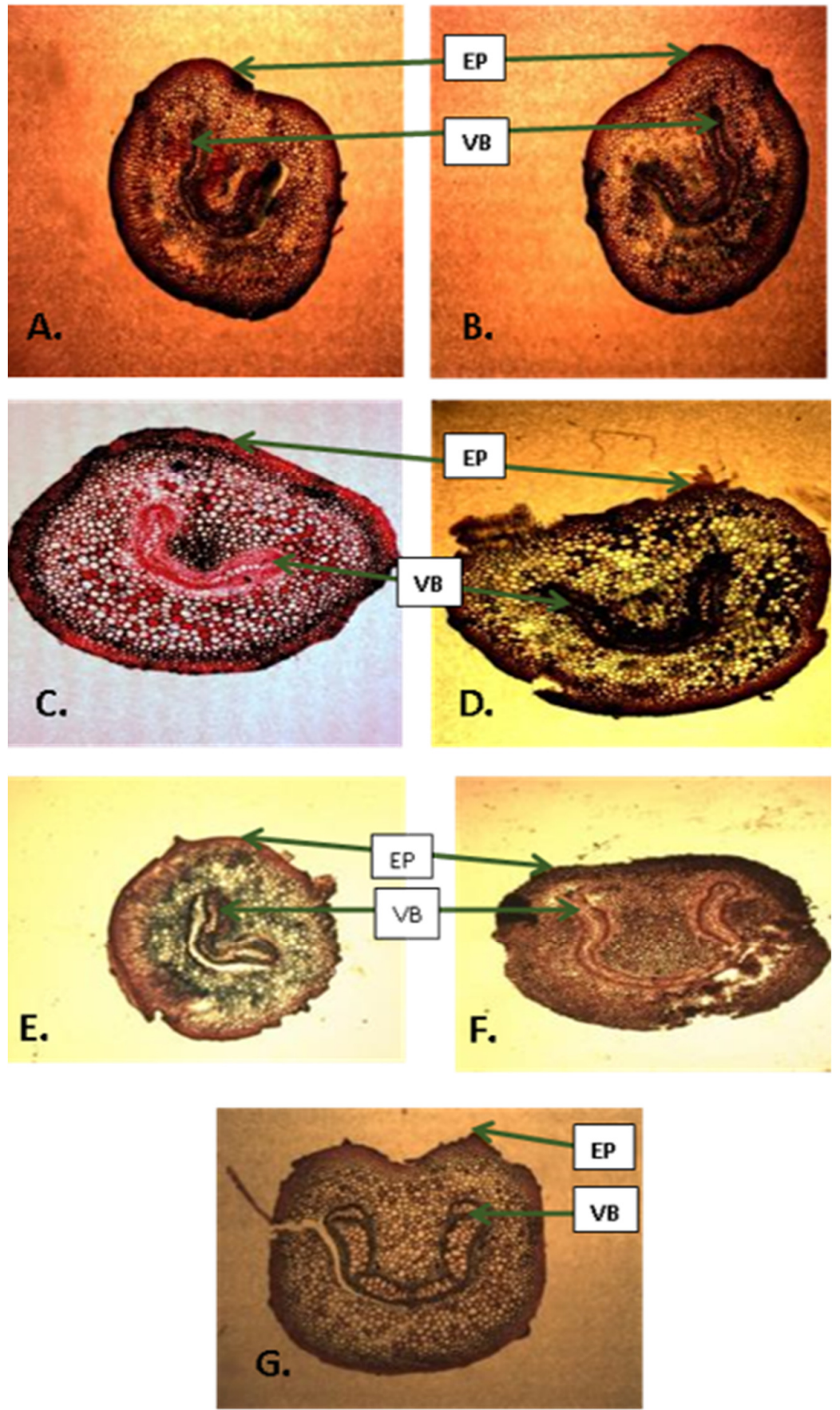

Figure 3. Transverse sections of distal regions of stipes showing outlines in seven species of Pteris studied. A: P. acanthoneura, B: P. atrovirens, C: P.ensiformis, D: P. mildbraedii, E: P.similis, F: P. togoensis and G: P. vittata

Legend: EP: Epidermis, VB: Vascular bundle, Bar $=1000 \mu \mathrm{m}$ 

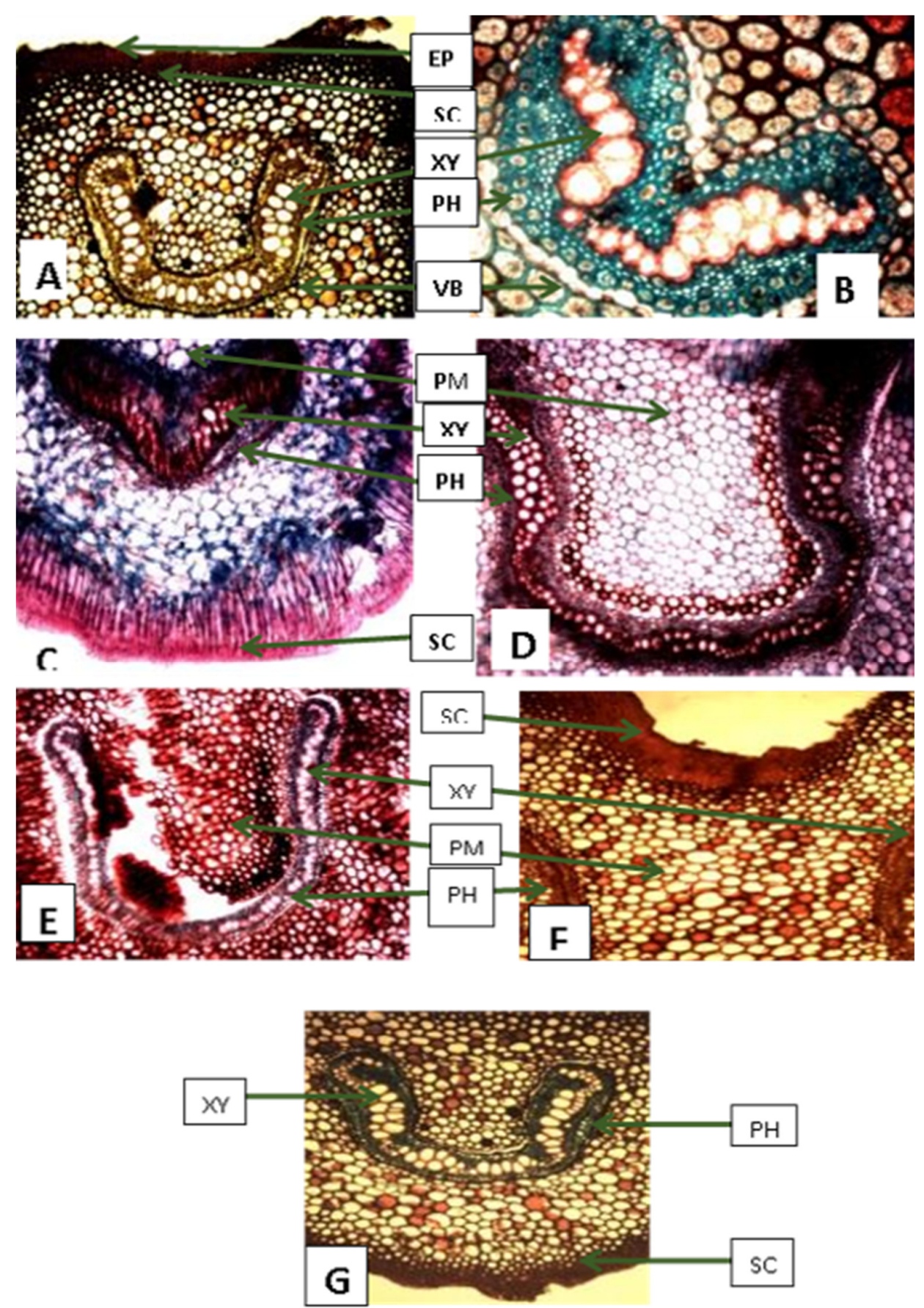

Figure 4. Transverse sections of proximal region of stipes showing cortex in Pteris species. $A$ : $P$. acanthoneura, B: P. atrovirens, C: P.ensiformis, D: P. mildbraedi, E: P. similis, F: P. togoensis and G: P. vittata

Legend: EP: Epidermis, VB: Vascular bundle, SC: Sclerenchyma, PH: Phloem, XY: Xylem, PM: Parenchyma, CO: Cortex., Bar $=1000 \mu \mathrm{m}$ 
8
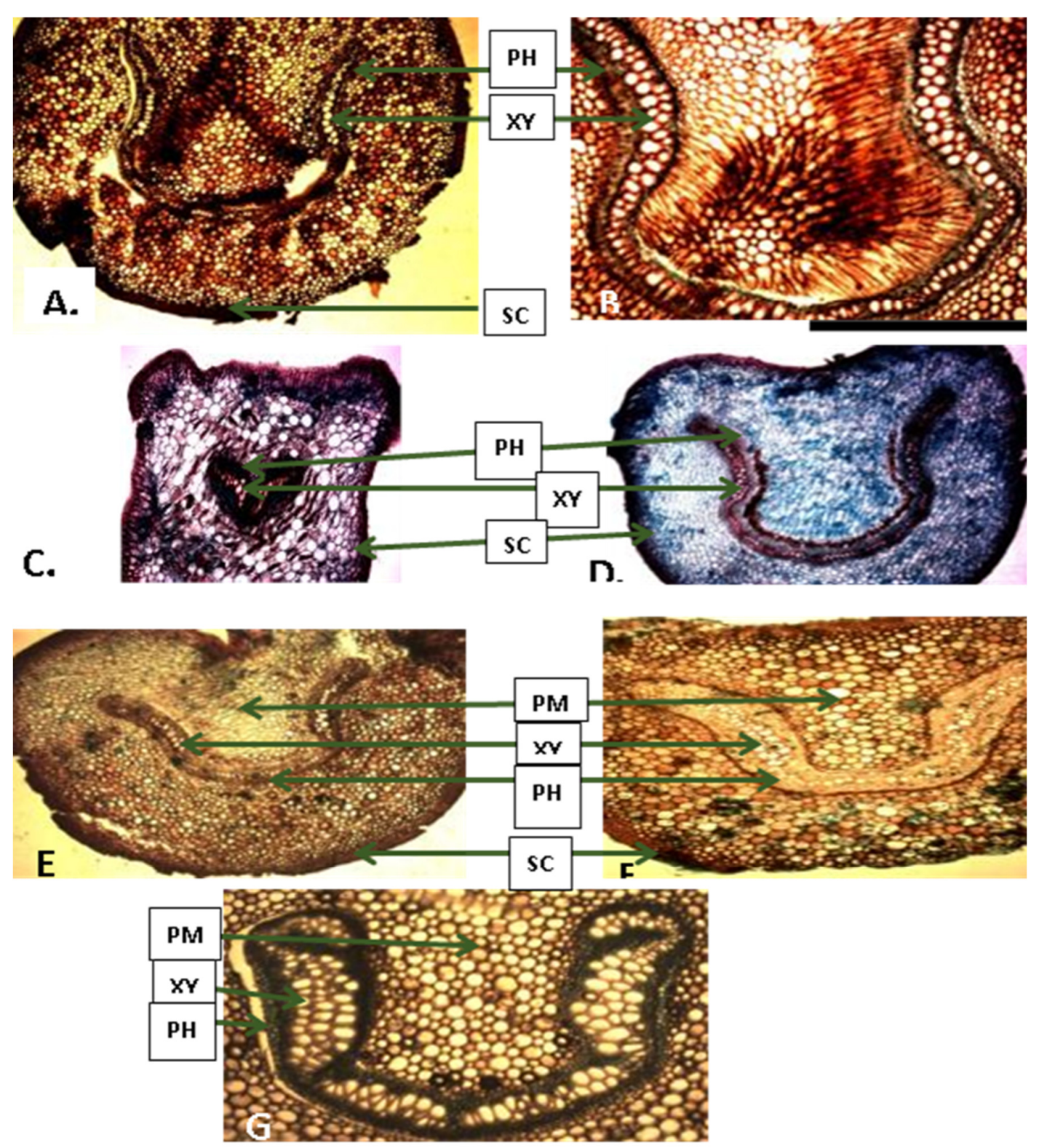

Figure 5. Transverse sections of median regions of stipes showing cortex in Pteris species. A: $P$. acanthoneura, B: P. atrovirens, C: P. ensiformis, D: P. mildbraedii. E: P. similis, F: P. togoensis, G:P. vitatta Legend: SC: Sclerenchyma, PH: Phloem, XY: Xylem, PM: Parenchyma, CO: Cortex 

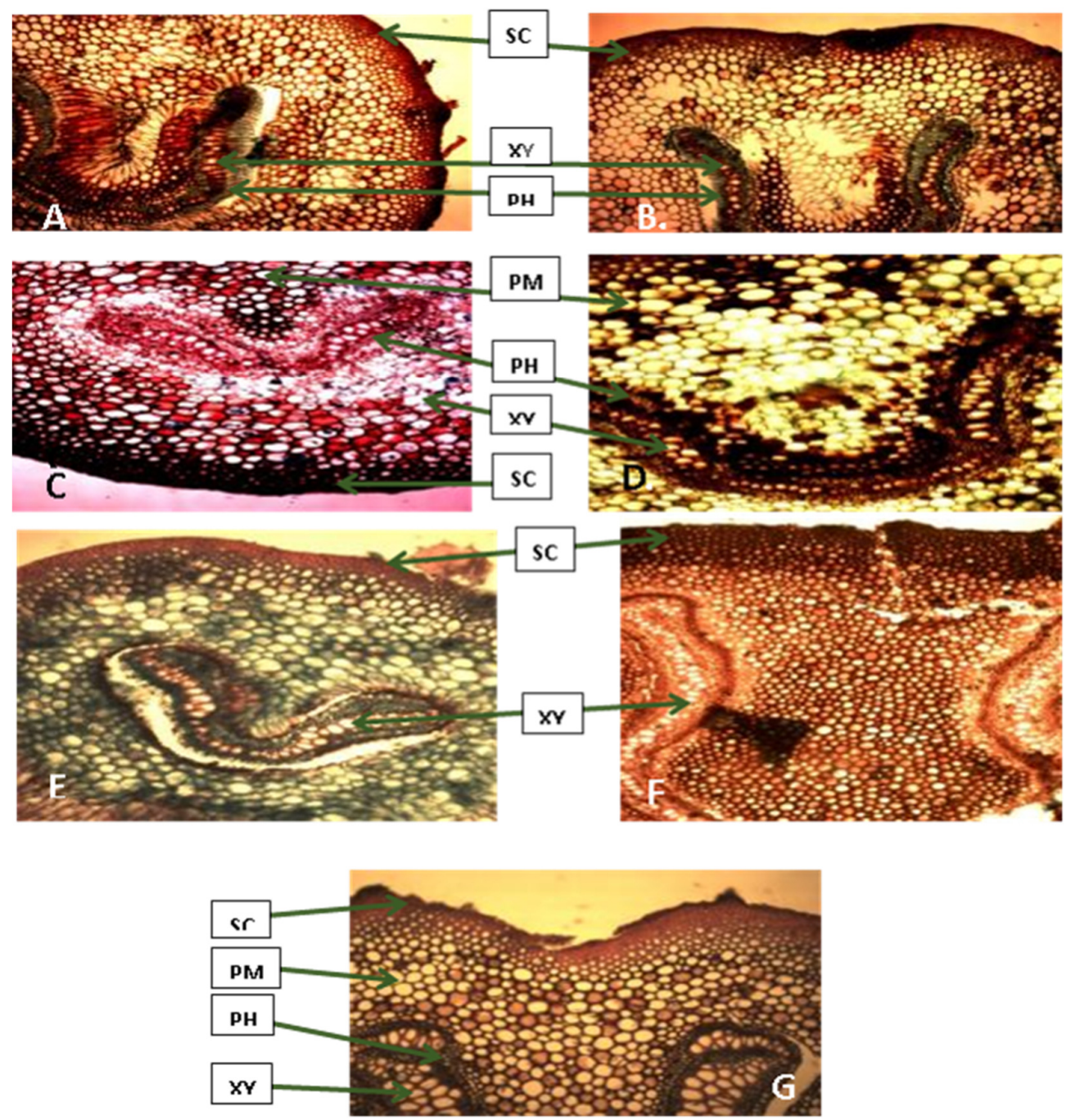

Figure 6. Transverse sections of distal regions of stipes showing cortex Pteris species. A: P. acanthoneura, B: P. atrovirens, C: P.ensiformis, D: P. mildbraedii, E: P. similis, F: P.togoensis, G P. vittata

Legend: SC: Sclerenchyma, PH: Phloem, XY: Xylem, PM: Parenchyma, VB: Vascular bundles

\section{Discussion}

Several authors consider the structure of vascular bundles significant in identifying the groups, these include Ogura (1972), Bondada et al. (2006); Olga and Ignacio (2012) among others. According to Pitterman et al. (2015), the stele of the early diverging Polypoids families including Saccolomataceae, Cystodiaceae, Lindasaceae, Loncititiaceae, Densteadiaceae and Pteridaceae are generally described as Omega(hippocampus) shape with some variations in the Cystodiaceae and Lonchitidaceae. Moreover, the exclusive presence of dictyostele in the petioles of more derived fern lineages suggests that the xylem structures was under strong selection for drought resistance during the Coenozoic period. Roux and Van Wyx (2000) clearly confirmed that stipe characters especially anatomy are more useful at the generic level and family level than at species level.

Anatomy of the transverse sections of the stipes of the species of the Pteris studied can be used to delimit them (Tables 1-3). The outlines vary from apple in $P$. acanthoneura, $P$. atrovirens and $P$. togoensis; cat's face in $P$. ensiformis and circular in $P$. similis. Grooves or depressions were observed in all regions of the stipe in all 
10

species except in $P$. ensiformis. The pattern and composition of tissues are almost uniform in all the species studied. The arrangement and shape of the vascular bundle varies and is of taxonomic importance in this genus. Generally, fused conjoint amphicribral arrangement is common to all the taxa but Omega shape vascular bundle is associated with $P$. acanthoneura, $P$. atrovirens, $P$. mildbraedii $P$ similis and $P$. togoensis, V-shaped in $P$. ensiformis and U-shaped in $P$. vittata.

Cell inclusions found in the petioles include crystal druses, styloids, starch granules and tannins (Figures 7-8). The distribution of cell inclusions in the petioles of the fern species may be utilized in delimiting some of the species. For instance, druses were present in proximal and median region of the stipe in $P$ acanthoneura, in all stipe regions in $P$. atrovirens and $P$. mildbraedii, styloids were peculiar to proximal regions in $P$. ensiformis and $P$. mildbraedii.

Table 1. Summary of the features in proximal regions of stipe of the Pteris species

\begin{tabular}{|c|c|c|c|c|c|c|}
\hline Species & $\begin{array}{c}\text { Adaxial } \\
\text { outline }\end{array}$ & $\begin{array}{c}\text { Abaxial } \\
\text { outline }\end{array}$ & Druses & $\begin{array}{c}\text { Starch } \\
\text { granules }\end{array}$ & Styloids & Tannins \\
\hline P. acanthoneura & Slightly concave & Convex & + & - & - & + \\
\hline P. atrovirens & Concave & Convex & + & + & - & + \\
\hline P. ansiformis & Flattened & Convex & + & - & + & - \\
\hline P. mildbraedii & Concave & Convex & + & - & + & + \\
\hline P. similis & Flattened & Convex & + & - & - & + \\
\hline P. togoensis & Concave & Convex & + & + & - & + \\
\hline P. vittata & Flattened & Convex & + & - & - & + \\
\hline
\end{tabular}

Legend: + Present; - Absent

Table 2. Summary of the features in median regions of stipes of the Pteris species

\begin{tabular}{|c|c|c|c|c|c|c|}
\hline Species & Adaxial outline & $\begin{array}{l}\text { Abaxial } \\
\text { outline }\end{array}$ & Crystals & Starch grain & Styloids & Tannins \\
\hline P. acanthoneura & Concave & Convex & - & - & - & + \\
\hline P. atrovirens & Concave & Convex & - & - & - & + \\
\hline P. ensiformis & flattened & Convex & + & - & - & - \\
\hline P. mildbraedii & Concave & Convex & + & - & - & + \\
\hline P. similis & Slightly concave & Convex & + & - & - & + \\
\hline P. togoensis & Flattened & Convex & + & + & - & + \\
\hline P. vittata & Concave & Convex & - & - & - & + \\
\hline
\end{tabular}

Legend: + Present; - Absent

Table 3. Summary of the features in distal regions of stipes of the Pteris species

\begin{tabular}{|c|c|c|c|c|c|c|}
\hline Species & $\begin{array}{l}\text { Adaxial } \\
\text { outline }\end{array}$ & $\begin{array}{c}\text { Abaxial } \\
\text { outline }\end{array}$ & Druses & Starch grain & Styloids & Tannins \\
\hline P. acanthoneura & Round & Convex & + & - & - & + \\
\hline P. atrovirens & Concave & Convex & + & - & - & + \\
\hline P. ensiformis & Flattened & Convex & - & - & - & - \\
\hline P. mildbraedii & Concave & Convex & + & + & - & + \\
\hline P. similis & Concave & Convex & - & - & - & + \\
\hline P. togoensis & Concave & Convex & + & + & - & + \\
\hline P. vittata & Concave & Convex & + & - & - & + \\
\hline
\end{tabular}



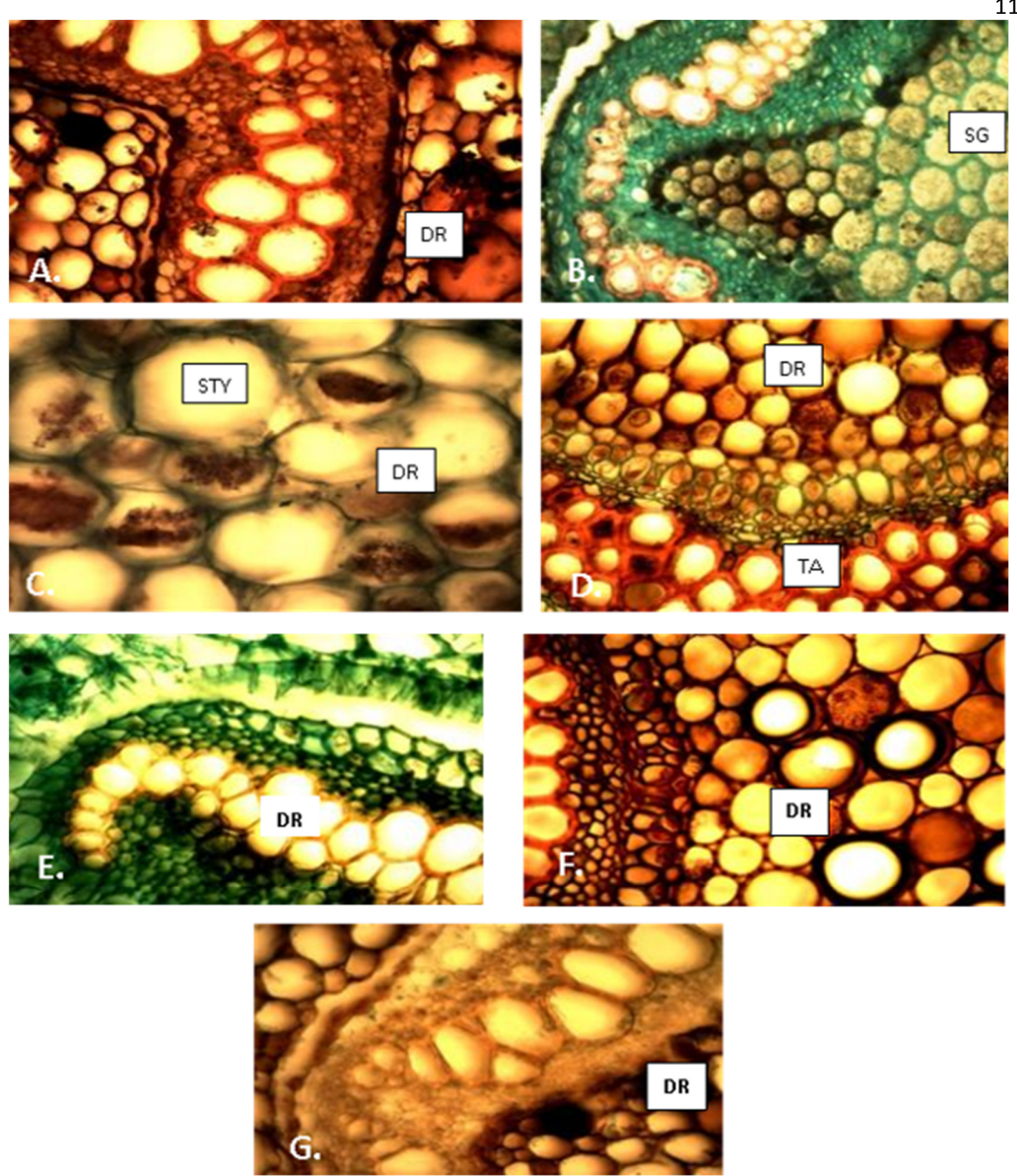

Figure 7. Ergastic substance in proximal stipe regions of Pteris species. A: Druses in xylem of $P$. acanthoneura, B: Starch granules in parenchyma of $P$. atrovirens; C: Styloids in xylem of $P$. ensiformis; D: Tannis and druses in parenchyma of $P$. mildbraedii, E: Druses in phloem of $P$ similis, $\mathrm{F}$ : Druses in phloem and parenchyma cells in P. togoensis, G :Druses in phloem of $P$. vittata

Legend: DR: Druses; SG: Starch granules, STY: Styloid, A: Tannins 

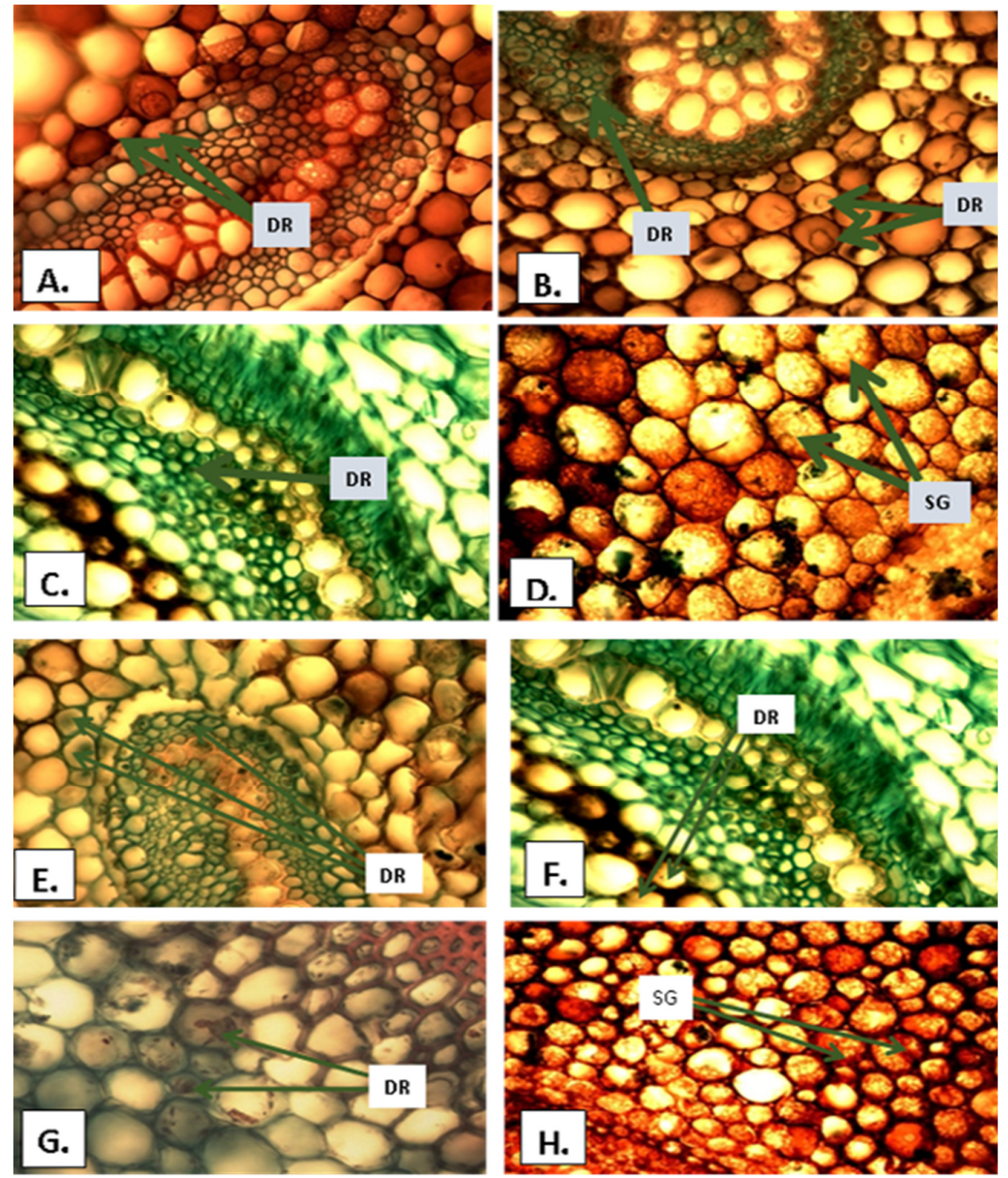

Figure 8. Ergastic substances in median (A-D) and distal (A-H) stipe regions of Pteris species. A: Druses in parenchyma cells of $P$. acanthoneura, B: Druses in phloem and parenchyma cell $P$. atrovirens, C: Druses in phloem cells of $P$. mildbraedii, D: Starch granules in $P$. togoensis, E. Druses in phloem and parenchyma cells of $P$. atrovirens, F: Druses in parenchyma of the cortex, $P$. mildbraedii, G: Druses in phloem cell of $P$. similis, $\mathrm{H}$ : Starch granules in $P$. togoensis

Legend: SG: Starch granules, DR: Druses

\section{Conclusions}

In conclusion, the seven Pteris species can be delimited based on their stipe anatomical characteristics. such as shape or stipe outline, cell and tissue arrangement of the epidermal layers. Stipe shapes in P. vittata and P. ensiformis deviates from the hippocampus type possessed by the most members of the family Pteridaceae. 


\section{Acknowledgements}

This research received no specific grant from any funding agency in the public, commercial, or not-forprofit sectors.

\section{Conflict of Interests}

The authors declare that there are no conflicts of interest related to this article.

\section{References}

Bondada B, Tu C, Ma L. (2006). Surface structure and anatomical aspects of Chinese brake fern (Pteris vittata: Pteridaceae). Britannia 58(3):217-228.

Ogura Y (1972). Comparative anatomy of vegetative organs of the Pteridophytes. Gebruder Borntraeger, Berlin, pp 1-39. Olga GM, Ignacio V (2012). The structure of petioles in Pteris (Pteridaceae). American Fern Journal 102(1)1-10.

Pitterman J, Watkin JE, Cary KL, Schuettpelz E, Broaderse C, Smith AR, Baer A (2015). The structure and function of xylem in seed free vascular plant: an evolutionary perspective. In: Ecological and functional xylem anatomy (Eds). Uwe Hacke, Springer International, pp 35.

Price MG (1974). A new section of species of Pteris. Kew Bulletin 29:725-730.

Remsi S, Thomas VP, Strinivas VK (2016) Stipe anatomical studies on selected pteridophytes of South India. Acta Botanica Hungarica 58(1-2):167-176.

Roux JP, Wyk Van AE (2000). Morphology and anatomy of the rhizome and frond in the African species of Polystichum (Pteropsida: Dryopteridaceae). Bothalia 30(1):57-68.

Roux JP (2009). Synopsis of the Lycopodiophyta and Pteridophyta of Africa, Madagascar and neighboring islands. Strelitzia 23, South African National Biodiversity Institute, Pretoria.

Ummu-hani B, Noraina, T, Maideen H, Damanhari AM, Sin-Rou G, Khatijah H, Ruzi AR (2013). Taxonomic value of the stipe anatomy in Davallia (Davalliceae). Maylasian Nature Journal 65(2-3):10-134.
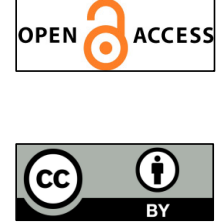

The journal offers free, immediate, and unrestricted access to peer-reviewed research and scholarly work, due SHST supports to increase the visibility, accessibility and reputation of the researchers, regardless of geography and their budgets. Users are allowed to read, download, copy, distribute, print, search, or link to the full texts of the articles, or use them for any other lawful purpose, without asking prior permission from the publisher or the author.

License - Articles published in Notulae Scientia Biologicae are Open-Access, distributed under the terms and conditions of the Creative Commons Attribution (CC BY 4.0) License.

(c) Articles by the authors; SHST, Cluj-Napoca, Romania. The journal allows the author(s) to hold the copyright/to retain publishing rights without restriction. 